\title{
DA SUJEIÇÃO AO AUTOCONHECIMENTO: A PRESENÇA DA PAIXÃO EM ENSAIO SOBRE A CEGUEIRA
}

Nefatalin Gonçalves Neto ${ }^{1}$

\begin{abstract}
RESUMO: Este artigo tem por objetivo trabalhar a questão da paixão no livro Ensaio sobre a cegueira de José Saramago. Partindo de sua conceitualização, procuramos verificar suas potencialidades no livro supracitado em relação, principalmente, à sujeição e aos processos de construção de identidade da personagem protagonista frente aos desmandos de uma humanidade decadente e vilipendiadora. Pretendemos, com base nesta investigação, propor algumas linhas diretivas de leitura dos textos do escritor português, bem como algumas reflexões sobre literatura enquanto espaço natural de expurgamento das paixões.
\end{abstract}

PALAVRAS-CHAVE: Assujeitamento; Empoderamento; Limiar; Sujeição; Paixão.

\section{FROM SUBJECTION TO SELFKNOWLEDGE: THE PRESENCE OF PASSION BLINDNESS}

\begin{abstract}
This article aims deal This article aims deal with the subject of passion in the book Blindness by José Saramago. Starting from its conceptualization, we sought to verify its potentialities in the work of this Portuguese author, mainly in relation to the subjection and to the identity construction processes of the protagonist character in front of the excesses of a decadent and vilifier humanity. We intend, based on this research, propose some reading guidelines of Saramago's texts, as well as some reflections on literature as a natural space of expugement of the passions.with the subject of passion in the book Blindness by José Saramago. Starting from its conceptualization, we sought to verify its potentialities in the work of this Portuguese author, mainly in relation to the subjection and to the identity construction processes of the protagonist character in front of the excesses of a decadent and vilifier humanity. We intend, based on this research, propose some reading guidelines of Saramago's texts, as well as some reflections on literature as a natural space of expugement of the passions.
\end{abstract}

Keywords: Subjectness; Empowerment; Sill; Subjection; Passion.

Ao Eder Rafael de Araújo, quintessência da amizade e do conhecimento.

A paixão não procede das pessoas, mas de algo a que elas têm de obedecer para não cumprirem apenas uma vida sem impulso e sem fantasia.

Agustina Bessa-Luís

Tornou-se lugar-comum enunciar que José Saramago foi comunista, ganhador do Prêmio Nobel de Literatura ou nascido em Azinhaga e não teve formação universitária. O escritor, um verdadeiro fenômeno frente aos grandes nomes lusitanos, brasileiros ou africanos de língua portuguesa da literatura, alcançou um patamar até então desconhecido

\footnotetext{
${ }^{1}$ Professor da Universidade Federal Rural de Pernambuco (UFRPE), Doutorando em Literatura Portuguesa pela Universidade de São Paulo (FFLCH/USP) sob orientação da Prof. Dra. Marlise Vaz Bridi e líder do grupo de pesquisa $O$ insólito na literatura.
} 


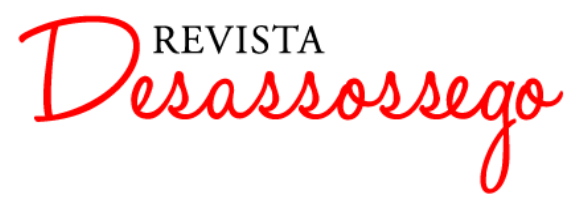

DESASSOSSEGO 16 | DEZ/2016 | ISSN 2175-3180

DOI: http://dx.doi.org/10.11606/issn.2175-3180.v8i16p35-49

no panteão de vendas e publicidade. Ao voltarmos nossos olhos para a produção crítica do autor constatamos, apesar de sua prolífera fama, ser pequeno o número de livros sobre sua obra (ainda não possuímos nenhum texto que colija criticamente todos os seus escritos, seus romances ou mesmo textos sistemáticos reflexivos sobre a trajetória de seus temas ou de seus lugares-comuns), mas que se contrabalanceia com uma exorbitante produção de dissertações de mestrado e teses de doutorado sobre sua obra completa - desde os livros ignorados pelo próprio escritor, passando por seus processos de escrita, engajamento político e literário e processos intertextuais, sem contar a infinidade de artigos que pululam em seminários, congressos, eventos e revistas acadêmicas, com destaque para a Revista saramaguiana, cujo intuito é publicar textos sobre o autor e sua profícua obra.

Ora, se a obra do autor vem recebendo atenção redobrada da crítica especializada, questões de cerne mais intimas são, muitas vezes, deixadas ao redor da reflexão mais aguda dos romances. Dentre tais, podemos destacar a problemática da paixão que cerceia tanto as personagens quanto os valores estéticos saramaguianos e cujo foco pouco se tem comentado até o presente momento. Como nosso intuito não é analisá-la em extenso na obra toda do escritor, elegemos uma pequena reflexão que se debruça sobre Ensaio sobre a Cegueira para averiguar o tratamento dado pelo escritor à paixão - entendida aqui enquanto oxímoro de desejo e sofrimento -, como ela se apresenta em suas reflexões e quais gerenciamentos poderemos daí pressupor.

O vocábulo paixão, para além de seu gasto significado de sentimento muito forte em relação a uma pessoa, objeto ou tema, é uma emoção violenta, capaz de dominar a conduta humana e afastá-la de uma capacidade de reflexão racional. Contudo, sua pluralidade pode angariar, ainda, o sentido de sofrimento, proveniente de sua raiz semântica mais remota. Uma rápida consulta a dicionários e enciclopédias assenta informações complementares ao conceito em suas possibilidades. Segundo o Houaiss (2001), o termo é originário do latim tardio passio, passionis, forma derivada de passus, particípio passado de patī (sofrer). Assim, seu significado lato conteria os sentidos de paixão, passividade e sofrimento. Já o dicionário Priberam (2016) esclarece que a paixão exige a "ação de suportar" em contrabalanço à “ação de sofrer” em um processo dialético, enquanto o Michaellis (2016) explicita que o vocábulo é um "hábito ou vício incontrolável, dominador" e, completa, ser uma "disposição contrária ou favorável a alguma coisa, que cega e impede a razão". Por fim, a Enciclopedia Treccani (2016) informa: "Nell'accezione 


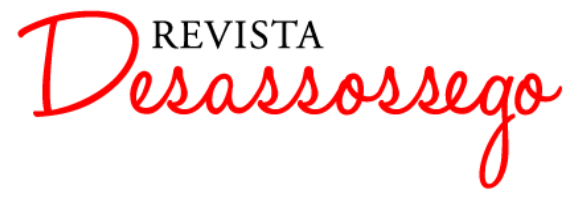

DESASSOSSEGO 16 | DEZ/2016 | ISSN 2175-3180

DOI: http://dx.doi.org/10.11606/issn.2175-3180.v8i16p35-49

comune, inclinazione esclusiva verso un oggetto, sentimento intenso e violento (di attrazione o repulsione) che può turbare l'equilibrio psichico e la capacità di discernimento e di controllo"2.

Ao recorrermos à filosofia, o termo se amplia e promove algumas viragens importantes. Já em Platão, a questão da paixão se impõe como desejo. Entretanto, para o filósofo grego esse desejo estaria voltado exclusivamente para o mundo das sombras, fato que faz o sujeito apaixonado abandonar a busca por um mundo ideal e se desviar do reto caminho. Para o filósofo, a paixão se contrapõe ao amor, exercício esse em que o amante busca no amado a Ideia - verdade essencial - não experienciada e/ou desconhecida. Dessa forma, o amado supre a falta da ideia primeira, torna-o pleno e, de modo dialético, recíproco. Já Aristóteles, em sua Ética a Nicômaco, conceitua a paixão (páthos) como o que move e/ou impulsiona o homem para a ação (praxis). Já na Retórica, o filósofo designa os afetos justamente sob o termo genérico de pathos. Do grego phatos, seu significado é sentimento e/ou sofrimento ${ }^{3}$. Assim, nessa rubrica filosófica se encaixam paixões fortes negativas ou positivas; ou seja, elas são como guias internas do agir humano, relacionadas intimamente com a moralidade, seja ela virtuosa (aretê) ou viciante (kakia): "Por paixões entendo os apetites, a cólera, o medo, a audácia, a inveja, a alegria, a amizade, o ódio, o desejo, a emulação, a compaixão, e em geral os sentimentos que são acompanhados de prazer ou dor; (...)" (ARISTÓTELES, 1979, p. 22).

Enquanto ingrediente psicológico das provas, o pathos produz comoção psíquica no público, daí seu poder catártico nas tragédias. Isso porque, ao conseguir um consentimento afetivo, a tragédia alcança, por meio da catarse (elemento causado pela exposição patética das personagens em ação no palco), a suscitação uma ação. O pathos age diretamente no enunciatário pois, como comenta Aristóteles, as paixões "são as causas que introduzem mudanças em nossos juízos” (1964, p. 100). Por conseguinte, na lista do estagirita figuram sensações acompanhadas de dor ou de prazer, que indiciam, para ele, ser virtuoso o homem cuja força consegue dominar suas paixões e optar pelo bem agir, enquanto aquele que se deixa levar por paixões é vicioso. Essas paixões são divididas em quatro tipos de disposições de caráter: continência e temperança (virtudes), incontinência e intemperança

\footnotetext{
${ }^{2}$ No sentido comum, inclinação exclusiva para um objeto, sentimento intenso e violento (de atração ou repulsão) que pode perturbar o equilíbrio mental e a capacidade de discernimento e controle (Tradução sob nossa responsabilidade).

${ }^{3}$ Dele originou-se o termo patético, empregado, atualmente, em sentido pejorativo para algo excessivamente afetado, como as novelas televisivas ou filmes demasiadamente sentimentais.
} 


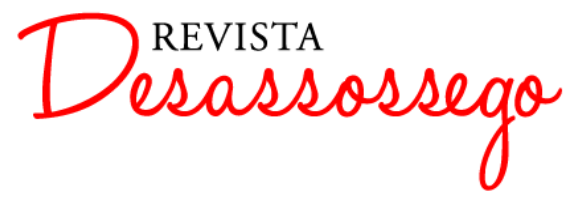

DESASSOSSEGO 16 | DEZ/2016 | ISSN 2175-3180

DOI: http://dx.doi.org/10.11606/issn.2175-3180.v8i16p35-49

(vícios). Após o filósofo grego, o tema será retomado por Santo Agostinho, principalmente em suas Confissões. Nelas, o santo declara ser o coração o recipiente do amor divino, por isso o conhecimento deve ser buscado através do amor. Assim, ele diferencia amor e luxúria, sendo um positivo e o outro negativo.

Contudo, talvez o maior teórico a pensar sobre as paixões seja Schopenhauer, em seu $O$ mundo como vontade e como representação. Nele, o filósofo alemão expõe que a beleza das coisas consiste em esta só existir enquanto possuir, com o ser humano, uma relação impessoal, distanciada e desprendida. Para este filósofo, o mundo não passa de uma representação, uma síntese entre o objeto e a consciência humana. O que há de real é a Vontade, uma força irracional - e, por isso, causa de todo sofrimento. Essa Vontade é a força motriz universal e, sua representação, o manifestar volitivo em ideias - das quais decorrem os fenômenos. Quando acreditamos na possibilidade de felicidade, isso se dá por uma única razão: o impulso biológico para perpetuar a espécie, chamado pelo filósofo de “impulso de vida”. A paixão torna-se o motor da Vontade, sua condição. Como destaca Barboza,

Por mais que tais pessoas se sintam envergonhadas diante do tema, basta pensar mais detidamente e notarão: a composição da próxima geração, a colocação de uma cria/nça no mundo é "um objetivo mais elevado e digno do que sentimentos exagerados e transcendentes, parecidos com bolas de sabão" (BARBOZA, 1997, p. 81).

Ou seja, Schopenhauer acredita ser o amor uma tática de nossa natureza para termos filhos - escravos do impulso de vida, permanecemos para além da morte naqueles a quem geramos. Para ele, o amor é um artifício que apenas os seres humanos possuem, e se valem dele para poder procriar a espécie e alcançar o sucessor perfeito. Assim, ele aponta Eros - o deus do amor (aqui entendido como paixão e, por isso, vontade) - como principal causador dos problemas; através de suas flechas envenenadas, esse deus nos embriaga de amor e se diverte confundindo-nos com truques e armadilhas. Segundo ele:

$\mathrm{O}$ que se anuncia na consciência individual como impulso sexual em geral que não se dirige para um indivíduo determinado do outro sexo é simplesmente a Vontade de vida em si mesma, e fora do fenômeno. $\mathrm{O}$ que aparece porém na consciência como impulso sexual orientado para um indivíduo determinado é, em si mesma, a Vontade enquanto quererviver de um indivíduo precisamente determinado. Neste caso, o impulso sexual, embora sendo de fato uma necessidade subjetiva, sabe pôr, com habilidade, a máscara de uma admiração objetiva, iludindo assim a consciência: pois a natureza precisa deste estratagema para atingir seus fins (SCHOPENHAUER, 2000, p. 10). 


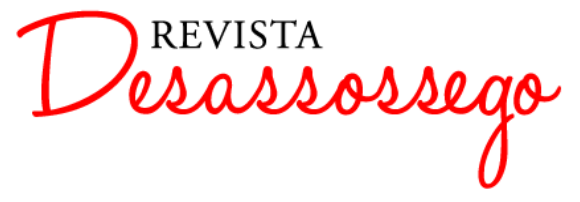

DESASSOSSEGO 16 | DEZ/2016 | ISSN 2175-3180

DOI: http://dx.doi.org/10.11606/issn.2175-3180.v8i16p35-49

Assim, o indivíduo age, sem o saber, a serviço da espécie, enquanto natureza de si para afirmar a indestrutibilidade do homem, que continua a viver na raça vindoura ou, como prefere Pernin, “(...) a finalidade da paixão é a procriação de um indivíduo especificamente determinado" (1995, p. 133). Condicionado a tal finalidade, essa vontade da espécie, “(...) é no ato procriador que o querer-viver se manifesta do modo mais direto sem intervenção do conhecimento, ou seja, como coisa-em-si, distinta da volição consciente" (LEFRANC, 2008, p. 135).

Ademais, o filósofo alemão chega a formular uma teoria poética na qual a arte possuiria o poder de suprimir, ainda que limitadamente, a submissão do conhecimento. Segundo Schopenhauer (2005), os conceitos racionais possuem uma existência secundária, derivados da Vontade. Assim, no geral o conhecimento permanece a serviço dessa Vontade. Como explicita Barboza, há um “(...) primado da vontade sobre o intelecto” (2001, p. 33), cujo privilégio não é apenas humano, mas essência de todos os fenômenos sejam eles animais, vegetais, minerais ou forças e energias da natureza. Ela também não possui consciência, operando de modo inconsciente em suas manifestações. Deste modo, existe, para o filósofo, uma espécie de Inconsciente Universal que Deseja, do qual a vontade humana seria exemplo; ou seja, uma unidade vital que rege e governa o mundo.

Ultrapassada a fase de acreditar-se indivíduo, o humano adquire conhecimento de sua identidade enquanto tal ${ }^{4}$. Dessa forma, Schopenhauer conclui que a Vontade possui um caráter cego e sem fundamento, donde decorre ser o sofrimento humano uma submissão aos anseios de nossos desejos, cujas satisfações não conduzem à felicidade, mas a outro desejo mais forte, ou seja, ela é uma paixão. Irmanado ao pensamento platônico de todo querer proceder de uma necessidade, o filósofo sugere que um modo de se libertar desse desejo seja a dissolução do eu; dito de outra forma, fugir ao querer, negá-lo em todas as suas formas e condições, voltar-se para um estado contemplativo. Ao atingir um estado de contemplação profundo, o ser, antes motor da distinção entre Eu e Objeto, passa a ser com esse objeto, constitui uma unidade, essência de uma união comum compartilhada, a Vontade:

Doravante não se trata mais do conhecimento individual, comum, cotidiano, brotando do intelecto-lanterna, correlato do princípio de razão em conluio com a vontade individual, mas sim do conhecimento estético, independente do princípio de razão, (...) O conhecimento, que

\footnotetext{
${ }^{4}$ Note-se, aqui, a proximidade das reflexões schopenhauerianas com a doutrina budista e o conceito panteísta de ser tudo e todos ao mesmo tempo.
} 


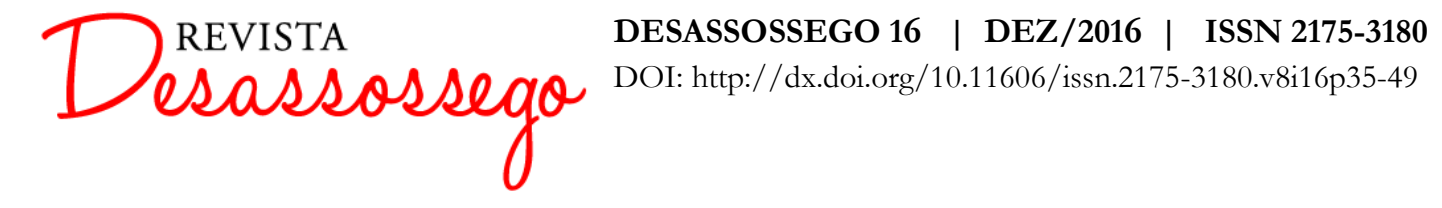

originariamente era mekané, servidor da vontade, passa a ser desinteressado e a vontade é negada, já que com a supressão da individualidade a vontade renuncia aos fins desejáveis de serem atingidos, logo, os motivos não têm mais eficácia sobre ela. (...) Resta tão-só uma unidade entre contemplador e contemplado (...) reflexos da unidade cósmica (BARBOZA, 2001, p. 60).

A experiência estética torna-se um momento de iluminação espiritual - quase um koan - no qual o Eu se despe de seus desejos e alcança o neutro, o sublime límpido, um estado do puro. O Belo - enquanto categoria estética, deixemos claro - engloba, para Schopenhauer, tudo o que seja capaz de causar um estado contemplativo, uma fuga ao querer e/ou ao desejo; isso porque no estado contemplativo o Eu não deseja, ele conhece o Objeto enquanto ideia platônica, forma plena, ideal. Assim, a arte funcionaria como um aliciante da pureza, obrigando esse Eu a conter seus desejos, tornar esse ser escapado à tirania da vontade, entrar em um estado de ataraxia que o conserva livre, torna-o "sujeito puro do conhecer". Dessa forma, se em Aristóteles a paixão era um pathos, em Schopenhauer essa paixão é, em caráter precário, a Vontade - motor da humanidade e elemento degradante dela.

Partindo de tais acepções, podemos constatar que, em sentido remoto (mas constante), a paixão acarreta o significado de sentimento. Em seu estado profundo, sua ideia demanda uma espécie de vício dominante do sujeito dela dependente, uma inclinação tão violenta que toma, por completo, a conduta do ser, afastando-o do desejável, da autonomia e da racionalização. Dessa possibilidade podemos extrair o significado de paixão enquanto sofrimento (como a Paixão de Cristo), pois essa inclinação chega ao limite de fazer o sujeito perder o domínio de suas qualidades mentais, colocando-o em estado agônico. Patogênica, ela carrega consigo, em todas as suas acepções, um conceito decantado para junto de valores negativos, um processo que, se a primeiro momento parece afetivo, transforma-se logo em sujeição. Ora, se a paixão para a sociedade hodierna se corporifica nos postulados de Schopenhauer (e sua posterior afirmação em Freud e seus conceitos de pulsão, inconsciente, dentre outros) de a humanidade não poder guiar-se por sua razão e escolher entre kakia e aretê, nos propomos a pensar como tais questões se revelam no corpo constitutivo do romance Ensaio sobre a cegueira, mais especificamente, na construção da personagem Mulher do médico. Parece-nos que, ao construir essa personagem, o narrador saramaguiano produz um desenvolvimento de ações possíveis de comprovar ser a paixão um pathos aristotélico, contrafeita à Vontade schopenhauriana. Mas, 


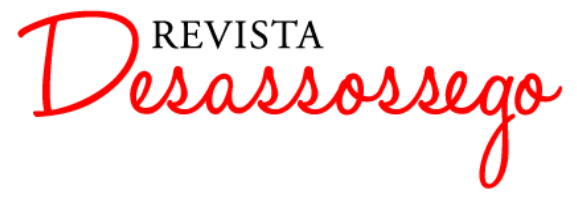

DESASSOSSEGO 16 | DEZ/2016 | ISSN 2175-3180

DOI: http://dx.doi.org/10.11606/issn.2175-3180.v8i16p35-49

mais que isso, o romance avança em um projeto - mesmo não premeditado ou engendrado precipuamente - de dialetizar tais paixões.

O enredo do romance, amplamente conhecido, descreve a situação de caoticidade de um mundo apocalíptico no qual todos ficam cegos, com exceção da Mulher do médico, a única personagem a não perder a visão. Intriga-nos a figura dessa personagem por ser ela, como já afirmamos em textos anteriores, a sustentadora de diversos níveis e elementos condicionantes da narrativa. O romance, ao estabelecer um universo dominado pelas paixões mais baixas e vis do humano, exige da única merecedora de visão uma posição e postura que nem sempre correspondem aos nossos pressupostos éticos ou anseios de leitor. Isso porque a Mulher do médico, menos que uma correspondente de ações, engajada ou tipificada, é uma personagem inacabada por viver no limiar da vida. Como já afirmamos,

O limiar está na dimensão da relatividade. Ele representa o local no qual a personagem descobre a si mesma e seu inacabamento. Contrário ao limite - em que a personagem não avança, mas fica interdita em seu posto - no limiar temos a migração constante da personagem em duas situações contrárias entre si, o que leva-a ao exercício de experimentação da verdade. É essa situação que se apresenta com grande evidência, por exemplo, em O Ensaio sobre a cegueira, de José Saramago (GONÇALVES NETO, 2010, p. 4).

Ao retomarmos o enredo do romance, encontramos momentos de alto grau de projeção do limiar, juntamente com os momentos de aguda vivência de paixões. Vejamos: após um rapaz cegar em plena rua, enquanto dirigia seu carro, uma espécie de cegueira branca começa por contaminar todas as pessoas, fator que leva o governo a tomar decisão drástica: alocar os novos cegos em antigos manicômios, separados da civilização e, conjuntamente, conclamar encontros e programas voltados para o conjunto de trabalhadores que lidam com a doença.

A primeira situação de grande conflito da narrativa se dá no final do terceiro capítulo, quando o Médico oftalmologista - uma das personagens do romance -, reconhece sua cegueira e está sendo levado para um dos espaços de cerceamento do governo:

Esperaram quase uma hora. Quando a campainha da porta soou, ela levantou-se e foi abrir, mas no patamar não havia ninguém. Atendeu ao telefone interno, Muito bem, ele desce já, respondeu. Voltou para o marido e disse-lhe, Que esperam em baixo, têm ordem expressa de não subir, Pelos vistos o ministério está mesmo assustado, Vamos. Desceram no elevador, ela ajudou o marido a transpor os últimos degraus, depois a entrar na ambulância, voltou à escada para buscar a mala, içou-a sozinha e empurrou-a para dentro. Finalmente subiu e sentou-se ao lado do 


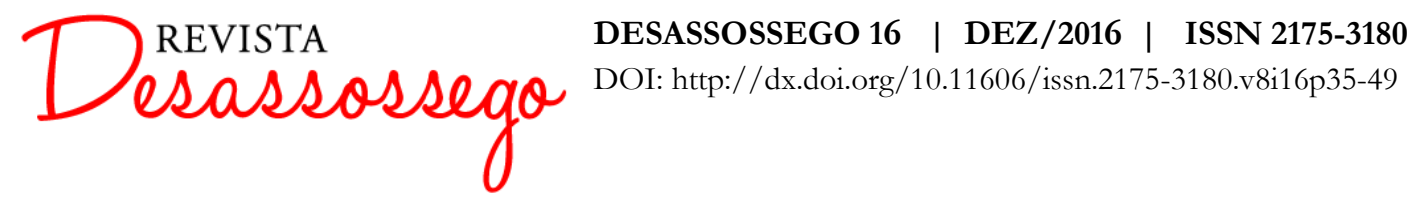

marido. O condutor da ambulância protestou do banco da frente, Só posso levá-lo a ele, são as ordens que tenho, a senhora saia. A mulher, calmamente, respondeu, Tem de me levar também a mim, ceguei agora mesmo (SARAMAGO, 1998, p. 44).

Nesse primeiro conflito, estabelecido no limiar da porta que marca a separação entre a segurança do lar e o espaço de desordem e alienação do monde à l'envers do universo romanesco saramaguiano em questão, a Mulher do médico opta, mesmo sendo possuidora da faculdade visual, acompanhar o esposo em sua peregrinação. A justeza e companheirismo da personagem, constantemente reforçada por um narrador benevolente e empenhado em descrições de minúcias caritativas e cuidados constantes, eleva a moral da personagem frente ao leitor e delineia sua atitude como ato amoroso, gratuito, de esposa/companheira. Destarte, nos parece que a personagem é imbuída de um pathos virtuoso, uma aretê emulante de compaixão e sentimentos positivos - mesmo que para isso a personagem se valha de uma mentira.

A paixão, no excerto, é movida por uma situação de limiar, cujo acontecimento exigiu uma práxis positiva; o segundo momento de alto grau de tensão narrativa acresce essa visão e acrescenta-lhe informações de grau. O momento se dá já no manicômio, quando a Mulher do Médico surpreende seu marido tendo uma relação sexual com a Rapariga dos óculos escuros:

Ou então, certas coisas o melhor é deixá-las sem explicação, dizer simplesmente o que aconteceu, não interrogar o íntimo das pessoas, como foi daquela vez que a mulher do médico tinha saído da cama para ir aconchegar o rapazinho estrábico que se havia destapado. Não se deitou logo. Encostada à parede do fundo, no espaço estreito entre as duas fileiras de catres, olhava desesperada a porta no outro extremo, aquela por onde tinham entrado num dia que já parecia distante e que não levava agora a parte alguma. Assim estava quando viu o marido levantar-se e, de olhos fixos, como um sonâmbulo, dirigir-se à cama da rapariga dos óculos escuros. Não fez um gesto para o deter. De pé, sem se mexer, viu como ele levantava as cobertas e depois se deitava ao lado dela, como a rapariga despertou e o recebeu sem protesto, como as duas bocas se buscaram e encontraram, e depois o que tinha de suceder sucedeu, o prazer de um, o prazer do outro, o prazer de ambos, os murmúrios abafados, ela disse. Ó senhor doutor, e estas palavras podiam ter sido ridículas e não o foram, ele disse. Desculpa, não sei o que me deu, de facto tínhamos razão, como poderíamos nós, que apenas vemos, saber o que nem ele sabe. Deitados no catre estreito, não podiam imaginar que estavam a ser observados, o médico decerto que sim, subitamente inquieto, estaria dormindo a mulher, perguntou-se, andaria aí pelos corredores como todas as noites, fez um movimento para voltar à sua cama, mas uma voz, disse, Não te levantes, e uma mão pousou-se no seu peito com a leveza de um pássaro, ele ia falar, talvez repetir que 


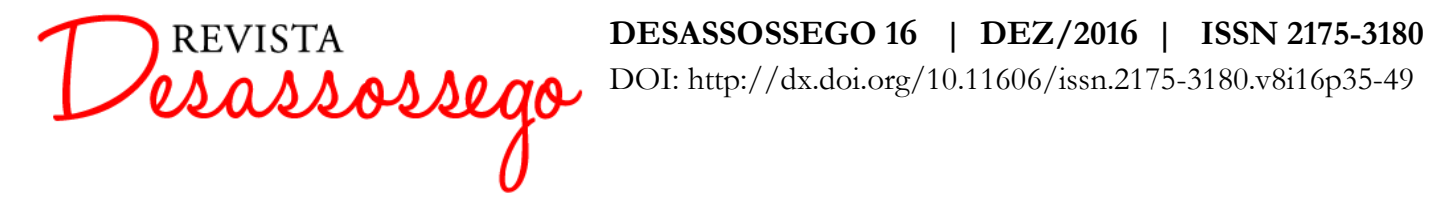

não sabia o que lhe tinha dado, mas a voz disse, Se não disseres nada compreenderei melhor. A rapariga dos óculos escuros começou a chorar, Que infelizes nós somos, murmurava, e depois, Eu também quis, eu também quis, $\mathrm{O}$ senhor doutor não tem culpa, Cala- te, disse suavemente a mulher do médico, calemo-nos todos, há ocasiões em que as palavras não servem de nada, quem me dera a mim poder também chorar, dizer tudo com lágrimas, não ter de falar para ser entendida. Sentou-se na borda da cama, estendeu o braço por cima dos dois corpos, como para cingi-los no mesmo amplexo e, inclinando-se toda para a rapariga dos óculos escuros, murmurou-lhe baixinho ao ouvido, Eu vejo (SARAMAGO, 1998, p. 171-172).

Apesar de extensa, reproduzimos toda a cena para não deixarmos escapar nuances de composição das paixões da protagonista. Vivendo em um espaço do limiar, infernal por natureza, as personagens se deparam, por conta da situação e do modo como são tratados, com suas ações e experiências mais degradantes. Caso houvesse algum tipo de pathos capaz de impulsionar a vida, ele estaria a ser completamente destruído. Igualmente, a condição degradante leva as personagens a abandonarem suas ações morais: os cegos da camarata quatro roubam a comida e trocam-na por dinheiro, joias e favores sexuais, a Rapariga de óculos escuros aceita dormir com aquele seu protetor, o marido abandona a mulher protetora para encontrar em outra o prazer e, por fim, uma mulher que tudo observa, ao invés de se encolerizar, age de forma amena, instaurando, a partir do abraço coletivo, uma fraternidade sexual.

A primeira vista, não nos parece que a premissa schopenhaueriana postulante de ser o homem um indivíduo que ama de menos, ou a mulher a possuidora de uma propulsão menor à traição, dá a tônica da cena. Contudo, por detrás do aparente conflito de traição instalada, outras coordenadas se delineiam. A primeira nota a ser extraída está na leve afirmação dada pelo narrador: "certas coisas o melhor é deixá-las sem explicação". Ora, a falta de explicação da situação, menos um problema, é apenas a constatação do processo de autoconsciência da personagem. Adentrada em um mundo à revelia, vivendo momentos decisivos, em constante estado de limiar, a Mulher do médico não possui um íntimo passível de ser compreendido. Sua confusão extrapola o nível narrativo, perpassa sua condição de subserviente, cuidadora, mãe, amiga, esposa ou mulher. Ao encostar-se à parede e procurar por alguma saída, a personagem apenas elabora, em si, qual sua práxis, suas possibilidades. Aquém de um amor diminuído (segundo Schopenhauer) ou uma busca de satisfação breve, a Mulher do médico representa, em sua constante, um caminho 


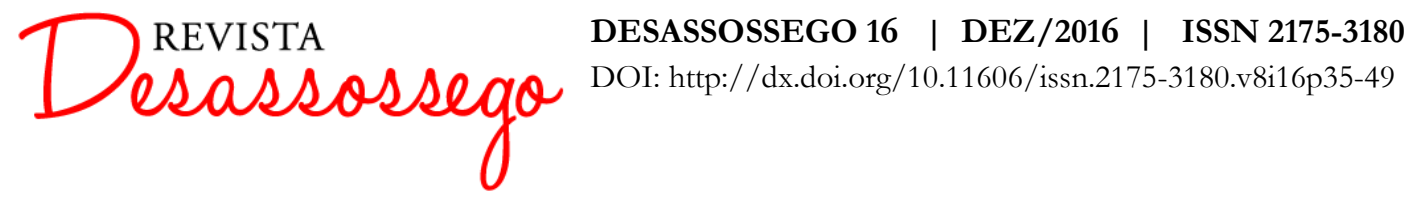

distante da excitação e próximo de uma suposta ataraxia: a conservação da vida e de seus entes queridos. Como explicita Cerdeira da Silva:

Essa é uma situação que não vale a pena explicar, porque as explicações se prendem a outra esfera de valores que envelheceram, e exigem, por isso, uma nova linguagem na qual possam conviver, por exemplo, o insignificante e o profundo que compõem os gestos de um sentido novo (CERDEIRA DA SILVA, 1999, p. 292).

Menos que assujeitar-se, a personagem elabora e passa a viver em um novo estado de valores - nos quais a paixão violenta se reprime em favor do advento da coletividade e do companheirismo; contra a dominação e a brusquidão dos atos, surgem as doces palavras. Diante da rigidez, a leveza por meio de um simples "não te levantes", completado com uma mão que "pousou-se no seu peito com a leveza de um pássaro". Temos a encenação de um silêncio compreensivo, de uma fala perdida na possibilidade de traduzir os atos e, ademais, as paixões. À infelicidade professada pela Rapariga dos óculos escuros, temos a suavidade de um ensinamento traduzida pela falta de palavras, e, por fim, quase poeticamente, vemos o erigir de um sentimento. Não à toa que, após vivenciar tais experiências, a personagem principal revele à então amante do marido: “eu vejo". O enlace criado dentro desse novo parâmetro de autognose suplanta segredos e projeta novos rumos para a sociedade e seus habitantes.

A narrativa, apesar de sua condição grotesca e escatológica, encaminha-se para um projeto fabular paralelo ao dos contos de fadas, no qual o herói passa por diversas peripécias antes de encontrar uma preleção final que muda os rumos da vida. Todavia, a Mulher do médico escapa à essas designações, comedimentos ou especulações teóricas por ser um ser em construção. O viés do condicionamento se quebra quando ela decide matar o líder da camarata quatro por ter sido molestada por ele:

Enquanto lentamente avançava pela estreita coxia, a mulher do médico observava os movimentos daquele que não tardaria a matar, como o gozo o fazia inclinar a cabeça para trás, como já parecia estar a oferecerlhe o pescoço. Devagar, a mulher do médico aproximou-se, rodeou a cama e foi colocar-se por trás dele. A cega continuava no seu trabalho. A mão levantou lentamente a tesoura, as lâminas um pouco separadas para penetrarem como dois punhais. Nesse momento, o último, o cego pareceu dar por uma presença, mas o orgasmo retirara-o do mundo das sensações comuns, privara-o de reflexos. Não chegarás a gozar, pensou a mulher do médico, e fez descer violentamente o braço. A tesoura enterrou-se com toda a força na garganta do cego, girando sobre si mesma lutou contra as cartilagens e os tecidos membranosos, depois furiosamente continuou até ser detida pelas vértebras cervicais. O grito mal se ouviu, podia ser o ronco animal de quem estivesse a ejacular, 


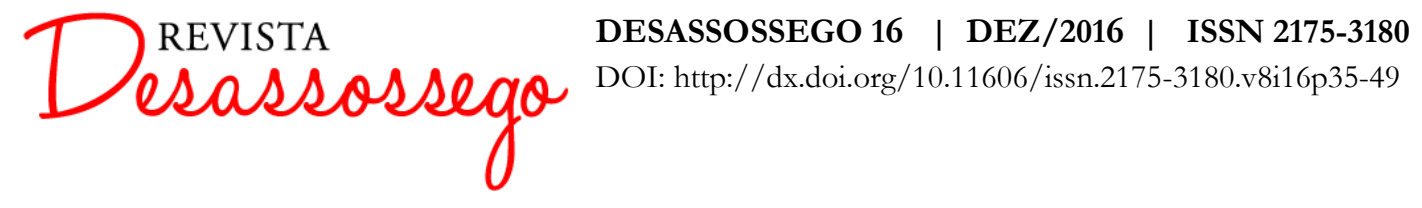

como a outros já estava sucedendo, e talvez o fosse, na verdade, ao mesmo tempo que um jacto de sangue lhe regava em cheio a cara, a cega recebia na boca a descarga convulsiva do sêmen (SARAMAGO, 1998, 185-86).

A minúcia descritiva do narrador e o processo textual que ora descreve o fato, ora os sentimentos e atitudes da Mulher do médico, torna a cena carregada de emotividade e faz o leitor experienciar, junto com a personagem, a ânsia de vingança levada a cabo. $\mathrm{O}$ jogo colorido (vermelho sangue, branco sêmen) realça a dualidade do narrado e instaura um posicionamento da personagem em evidente construção de uma nova ética. O branco da pureza rebaixado pelo ato vil é enobrecido pelo vermelho do sangue que se derrama como novo sacrifício pascal em beneficio de uma comunidade toda.

Ao optar por matar seu opressor, a protagonista alça um voo que ultrapassa sua mera posição sujeito interessado na coletividade. A construção fabular encantatória dos contos de fadas cai por terra e a personalidade do Eu aflora, em laivos de identidade que, para se firmar como tal, execra suas intempéries - as perturbações de ânimo. De guia e espelho do mundo, a Mulher do médico torna-se um sujeito egóico, vil, vingador. A personagem reconhece ser impossível dissolver-se (negando mais uma vez a condição schopenhauriana de libertação) e passa a sacrificar-se menos para salvar a si e aos outros.

Após a saída do manicômio, paulatinamente o romance passa a focar as transformações da personagem principal, assim como seus apetites e paixões. Ao tomar diferentes posições em diversas situações, a Mulher do médico revela-se cindida, dividida entre posições, necessitada de optar para se construir. Entre ameno e estável, revoltado e colérico, seu estado emocional reflete o inacabamento de sua construção: oxímoro fundamental para sua sustentabilidade. Ao comentar sobre o assassínio, a personagem reconhece: "Sim, matei-o eu, Porquê, Alguém teria de o fazer, e não havia mais ninguém" (SARAMAGO, 1998, p. 189); em outras palavras, a personagem assume sua constituição dialética e processual.

Essa gangorra sentimental e de posições expressa o modus vivendi pretendido pelo romance: o ser humano é mutável por natureza; vive em um processo contínuo de transformações. Dessa forma, distante do conceito schopenhauriano de sujeito escravo de suas paixões, o romance saramaguiano vincula-se a uma ideia clássica de paixão, na qual a individualidade e a consciência são fundamentais, além de projetar uma visão dialética do ser na qual a situação molda os sujeitos. Como bem expressa a Mulher do médico: 


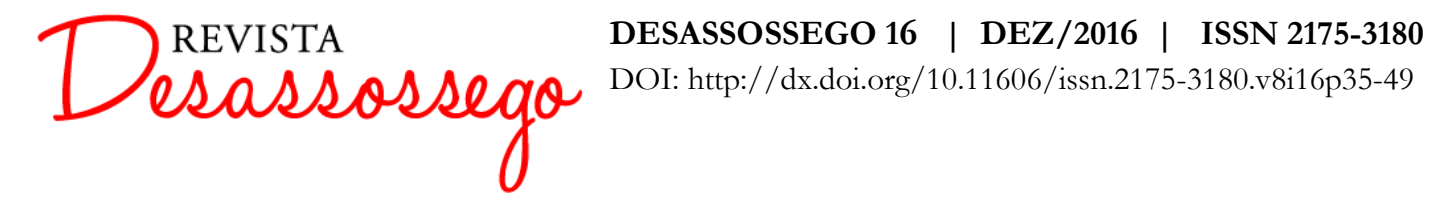

(...) o certo e o errado são apenas modos diferentes de entender a nossa relação com os outros, não a que temos com nós próprios, nessa não há que fiar, perdoem-me a preleção moralística, é que vocês não sabem, não o podem saber, o que é ter olhos num mundo de cegos, não sou rainha, não, sou simplesmente a que nasceu para ver o horror, vocês sentem-no, eu sinto-o e vejo-o, (...) (SARAMAGO, 1998, p. 262).

O romance transfere, em sua construção, a atenção do sujeito como assujeitado uma espécie de objeto pronto - para seu processo de construção. Temos a enunciação do ser e não mais o imperativo do ter de ser (produto). Sem assumir projetos institucionais, mas em constante emancipação identitária (conforme permite seu trânsito pelos espaços descritos no romance), a Mulher do médico - atravessada por situações, perspectivas e/ou discursos - torna-se parte atuante de seu meio e, como ele, em devir. Dessa forma, Saramago retoma, conceitualmente, a postura de Aristóteles em sua Ética a Nicômaco para questionar os pressupostos schopenhaurianos, demonstrando ser a práxis, e não a Vontade apriorística, a dirigente das ações humanas. Ademais, enxerga na práxis do ser o projeto fundamental de sua identidade, um ser em devir. Ultrapassando o sentido ilusório de perpetuar-se no outro, o romancista português empodera os seres humanos de suas escolhas, comprova que refletir sobre as paixões é uma questão polêmica, exige discussões e aponta para posições e situações múltiplas.

Ao recorrermos ao pensamento bakhtiniano, podemos encontrar, em suas reflexões e análises sobre a constituição do romance polifônico, alguns dados complementares ao caminho traçado até o momento. Segundo o pensador russo, a polifonia de uma obra refere-se à incorporação, no corpo do texto, de uma voz (ou de vozes) outra(s) no enunciado. Dessa forma, a construção textual configura-se em fins diversos, perdendo a intencionalidade do autor como centro irradiador de sentido. Como explicita o pensador, temos no romance polifônico "consciências eqüipolentes e seus mundos que aqui (no romance) se combinam numa unidade de acontecimento, mantendo a sua imiscibilidade." (BAKHTIN, 1998, p. 4, grifos do autor). Ora, se pensarmos o Ensaio sobre a cegueira como um romance não polifônico, mas em busca desse projeto e postura, a voz da Mulher do médico se equipara a diversas outras vozes do romance e mesmo à do narrador. O confronto e a divergência das posturas passionais são compostas para, logo após, serem derrubadas, nunca com veridicidade de alguma.

O conceito de sujeito, de forma geral, dicionarizado, é definido como dependente, submisso, subordinado. No romance saramaguiano, entretanto, essa postura é ultrapassada 
por meio de um sujeito cindido e, ademais das regras anônimas, históricas e determinadas pelo tempo/espaço de sua época, por quesitos sociais, econômicos, geográficos ou linguísticos, instaurado no confronto, no processo de, em uma construção constante, heterogeneamente, entre instabilidade e estabilidade - sem aceitação de primazias estruturais. Dito de outra maneira, o Ensaio sobre a cegueira propõe um discurso calcado no artifício dialético de destruições e reconstruções ideológicas no qual ficam expostos, ao leitor, os processos de construção e manipulação do mundo. Assim, a protagonista aprende - e nós leitores com ela - não existir liberdade plena: somos cercados por obrigações diversas, cujo acontecimento coage-nos a desempenhar diferentes papéis, além de diversas coerções discursivas e projetos ideológicos cerceantes.

O romance defende, mesmo a contracorrente, a famigerada capacidade do homo sapiens de guiar-se por seu intelecto e razão, combatendo a premissa freudiana - e de seu influenciador, o filósofo do pessimismo - de o comportamento atual da humanidade ser um esforço destinado a provar a suas teses e hipóteses. E o faz construindo uma personagem fugidia dos moldes clássicos, guiada pela razão, possuidora de um apetite dócil, “temperante", sem "apetites excessivos nem maus" (ARISTÓTELES, 1979, p. 12), e, ao mesmo tempo, estigmatizada por ações vis, violentas e furiosas. Contudo, mesmo resgatando o projeto aristotélico, o romancista dos tempos pós-modernos ${ }^{5}$ aponta para o projeto de um sujeito dialeticamente temperante - capaz de abandonar seus apetites pela boa dita e a reta razão - mas, quando necessário, conveniente ou sem justificativa qualquer, ser também intemperante.

Ao modo de conclusão das reflexões aqui levantadas, tendo em vista ser a Mulher do médico uma personagem que transita entre essências, constante tensão, disposta no limiar da vida, dinâmica e sempre em luta contra seu assujeitamento, somos, obrigatoriamente, encaminhados para uma última questão: por que essa personagem não perde sua visão?

Diversas podem ser as respostas e mesmo não existir uma conclusiva para a questão. Contudo, dadas as reflexões realizadas, podemos pensar que Ensaio sobre a cegueira apresenta um processo de escrita acerca do oikess ${ }^{6}$ humano. Por tal, essa morada seria sua identidade - um construto em devir. Destarte, a cegueira branca - fato inexistente -

\footnotetext{
${ }^{5}$ Usamos com ressalva o termo pós-moderno por acreditarmos que o Saramago, apesar de algumas marcas nitidamente pós-modernistas, não ser um escritor vinculado a essa perspectiva.

6 Proveniente do grego morada.
} 


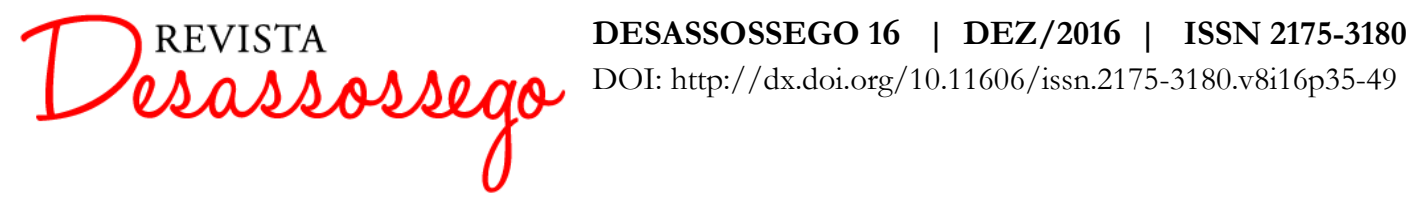

representa, simbolicamente, uma doença aliciante, dominadora do ser, fraudulenta ao intentar esconder a verdade - afinal, os sujeitos acreditam enxergar tudo quando, na verdade, veem apenas o branco do nada. Dessa forma, a cor branca, produto da junção de todas as outras cores, representa um vazio por não ter nenhuma tonalidade. As ideologias sujeitantes promovem um constante desenraizamento profundo dos seres, cegam-nos, impedem-nos de ver sua incompletude. Talvez por isso o autor, pela boca da personagem, expresse:

Por que foi que cegámos, Não sei, talvez um dia se chegue a conhecer a razão, Queres que te diga o que penso, Diz, Penso que não cegámos, penso que estamos cegos, Cegos que vêem, Cegos que, vendo, não vêem. (SARAMAGO, 1998, p. 310).

O romance faz o mapeamento de tal processo quando desterritorializa os seres assujeitados e obriga-os a viver em um mundo sem esse condicionamento. Ao manter-se fiel à capacidade de se reconstruir, mudar, desassujeitar-se, a Mulher do médico encontra, no vazio identitário, suas virtualidades em tensões opostas cujo complemento se dá na experiência vivida.

Ser em construção, a personagem expressa, por sua figura, que agir ou não é uma escolha própria, um "princípio motor" gestado no Eu e sua ativação revela o caráter humano. Ou, nas palavras de Bakhtin: "a verdade não nasce nem se encontra na cabeça de um único homem; ela nasce entre os homens, que juntos a procuram no processo de sua comunicação dialógica” (1998, p. 110, grifos do autor).

\section{REFERÊNCIAS BIBLIOGRÁFICAS}

ARISTÓTELES. Arte retórica e arte poética. Trad. Antonio Pinto de Carvalho. São Paulo: Difel, 1964.

Ética a Nicômaco. In: Aristóteles. "Os Pensadores". Trad. L. Vallandro e Gerd

Bornheim. São Paulo: Abril Cultural, 1979.

BAKHTIN, Mikhail. Problemas da poética de Dostoievski. Trad. Paulo Bezerra. $3^{a}$ ed. São

Paulo: Forense Universitária, 1998.

BARBOZA, Jair. Schopenhaner: a decifração do enigma do mundo. $2^{a}$ ed. São Paulo:

Moderna, 1997. - A Metafísica do Belo de Arthur Schopenhauer. São Paulo: Editora Humanitas, 2001. 


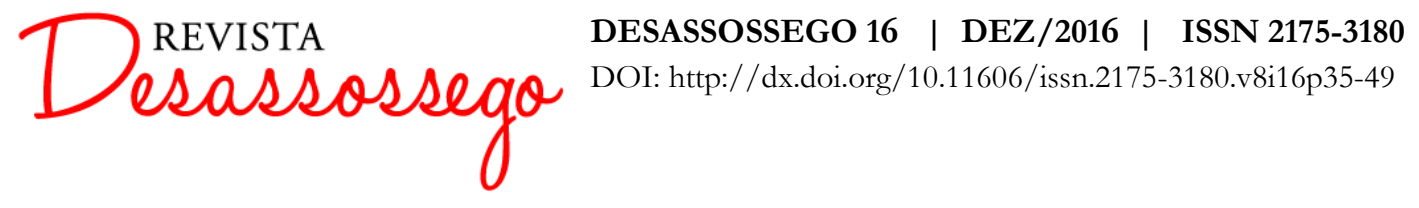

CERDEIRA DA SILVA, Teresa Cristina. De cegos e visionários: uma alegoria finissecular na obra de José Saramago. In: Berrini, Beatriz. José Saramago: uma homenagem. São Paulo: Educ, 1999, p. 287-95

Dicionário Michaelis on-line. Disponível em: http://michaelis.uol.com.br/. Consultado em: 19/06/2016.

Dicionário Priberam da Lingua Portuguesa. 2008-2013, Disponível em: https://www.priberam.pt/dlpo/. Consultado em 19/06/2016.

Enciclopedia Trecanni. Disponível em: http://www.treccani.it/enciclopedia/. Consultado em 19/06/2016.

GONÇALVES NETO, Nefatalin. A questão do limiar em Ensaio sobre a Cegueira: uma reflexão à luz das pesquisas bakhtinianas. In: Revista Desassossego, vol. 4, p. 1-10, 2010.

HOUAISS, Antônio. Dicionário Honaiss da Lingua Portuguesa. Rio de Janeiro, Ed. Objetiva, 2001.

LEFRANC, Jean. Compreender Schopenhauer. Trad. Ephraim Ferreira Alves. Petrópolis, RJ: Vozes, 2008.

PERNIN, Marie-José. Schopenhauer: decifrando o enigma do mundo. Rio de Janeiro: Jorge Zahar Editores, 1995.

SARAMAGO, José. Ensaio sobre a cegueira. São Paulo: Companhia das Letras, 1998.

SCHOPENHAUER, Arthur. Metafísica do amor, metafísica da morte. São Paulo: Martins Fontes, 2000.

O mundo como vontade e como representação. Trad. Jair Barboza. São Paulo: EdUNESP, 2005. 